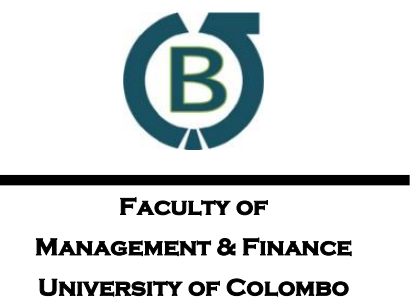

\title{
The Effect of Owner-Based and Lender-Based Governance Mechanisms on the Financial Performance of Listed Companies in Sri Lanka
}

\author{
G. Y. Ekanayake ${ }^{\mathrm{a} \varpi}$, Samanthi Senaratne ${ }^{\mathrm{b}}$, A. A. Azeez ${ }^{\mathrm{c}}$ \\ ${ }^{a}$ Department of Accounting, University of Colombo, Sri Lanka \\ ${ }^{b}$ Department of Accounting, University of Sri Jayewardenepura, Sri Lanka \\ ${ }^{c}$ Department of Finance, University of Colombo, Sri Lanka
}

\begin{abstract}
This study examines the effects of both Owner-based and Lender-based governance mechnisms on the firm financial performance in terms of three aspects, namely profitability, firm value and firm survival. From the Colombo Stock Exchange, the current study selected a sample of 100 listed entities in which the debt capital is a key source of financing. The results indicate that Owner-Governance mechanisms would enhance the firm profitability where, Lender-Governance mechanisms deteriorate it. However, the latter aids sustain the corporates, by attenuating firm distress level. In conclusion, the two types of corporate financiers have got divergent expectations which they try to assure through their own governance mechanisms over the entity (investee), as reflected through different effects on three aspects of firm financial performance. Thus, both governance mechanisms need to be considered as important factors in determining the different aspects of firm financial performance.
\end{abstract}

Keywords: Firm Distress Level, Firm Profitability, Firm Value, Lender-Governance, Owner-Governance

$\begin{array}{lll}\text { Received: } & \text { Accepted revised version: } & \text { Published: } \\ \text { 02 August 2019 } & \text { 07 November 2019 } & \text { 31 December 2019 }\end{array}$

Suggested citation: Ekanayake, G. Y., Senaratne, S., \& Azeez, A. A. (2019). The effect of owner-based and lender-based governance mechanisms on the financial performance of listed companies in Sri Lanka. Colombo Business Journal. (10)2, 103-133

DOI: http://doi.org/10.4038/cbj.v10i2.52

C 2019 The Authors. This work is licenced under a Creative Commons Attribution 4.0 International Licence which permits unrestricted use, distribution, and reproduction in any medium, provided the original work is properly cited.

\ gimhaniekanayake@gmail.com: (iD) https://orcid.org/0000-0002-6437-0209 


\section{Introduction}

How corporates are governed is essentially discussed in terms of the monitoring mechanisms used by different stakeholders of the firms. Throughout the past decades, Corporate Governance (CG) research has concentrated on the governance executed by the shareholders, among several other stakeholders of a firm (Day, Mather, \& Taylor, 2014). However, it is noteworthy that modern corporates across the globe are largely financed by debt capital also in addition to equity capital (Bhojraj \& Sengupta, 2003; Lorca, Sánchez-Ballesta, \& García-Meca, 2011; Bakar, Khan, Mather, \& Tanewski, 2018). Thus, the second main stakeholder of such levered companies would be the lenders, whose governance mechanisms too need to be considered as a part of CG. Since they have invested their money in the company, the financiers of the entities look forward to firm outcomes and benefits for themselves (Piot \& Missonier-Piera, 2009; Jiraporn, Chintrakarn, Kim, \& Liu, 2013). They are entitled to expect satisfactory paybacks from the corporation for the money they have invested. With this basis, CG ought to primarily focus on ensuring the returns for the financiers; both owners and lenders of the corporations, by mitigating the agency costs incurred by them (Shleifer \& Vishney, 1997).

Despite the above facts, it is surprising to note that themechanism through which lenders govern corporates and its possible impacts on firm financials have been overlooked in the Corporate Governance research agenda. Consequently, there is a significant dearth of literature on possible effects of lender-based governance mechanisms on firm financial performance. Considering both its importance and yet lacking focus, Baird and Rasmussen (2006) named lender governance as a 'missing lever' of CG. Adding to this, Tung (2009) recognized the important role of lender governance in CG and designates it as 'unsung influence of private debt'.

Three key outcomes of a profit-oriented firm may be maximising firm profitability and firm value and ensuring the firm survival. Several governance mechanisms are used by different stakeholders in order to maximise their own interests through the above firm outcomes. Thus, it is exciting to observe how the governance mechanisms executed by owners and lenders contribute to the aforementioned three outcomes of a corporation. There is a vast literature on the empirical findings suggesting that ' $C G$ mechanisms' significantly improve firm financial performance and the firm value (Brown \& Caylor, 2006; Balasubramanian, Black, \& Khanna, 2010; Black, Jang, \& Kim, 2006; Gompers, Ishii, \& Metrick, 2003; Klapper \& Love, 2004; Malik \& Makhdoom, 2016; Pillai \& Al-Malkawi, 2018). Nonetheless, the impact of CG practices on firm survival or the going concern has 
not been studied, leaving a huge gap in the related knowledge. Besides, limited studies are addressing the effect of lender governance mechanisms on firm results (Smith \& Warner, 1979; Ang, Cole, \& Lin, 2000; Tung, 2009; Byers, Fields, \& Fraser, 2008). Moreover, prior researchers have separately investigated the impacts of these two governance mechanisms and therefore have failed to identify the impacts of both mechanisms on firm results in a comparable way, which remains a major gap of CG literature. On the other hand, according to the Bowman's (1980) 'Risk Paradox Theory' that is predicting a negative association between risk and returns, lenders through their controlling mechanisms expect to minimizse the risk of firm's investment activities in order to minimizse the default risk, which may consequently lead to reduction in the returns of the firm. Neverthesless, contrary to above risk paradox theorem, most of the existing studies suggest that the lender-governance mechanisms increase the firm performance through curbing managerial misbehavior, improving operational efficiency and reducing cost of debt (Smith \& Warner, 1979; Ang et al., Cole \& Lin, 2000; Byers et al., Fields \& Fraser, 2008). Thus, it is compelling to recheck and confirm this relationship and analyse the possible outcomes.

In addressing the above knowledge gaps, the current study examines the effects of two types of governance mechanisms employed by owners and lenders on firm financial performance. In Sri Lanka, currently the average corporate debt ratio is around $43 \%$ (Bloomberg, 2016). Several studies regarding the corporate capital structure have also documented that there has been a high corporate leverage in Sri Lanka over recent years (Pratheepkanth, 2011; Vijayakumaran, 2015; Gamlath, 2019). Thus, as literature suggests (Tung, 2009; Baird \& Rasmussen, 2006), being a main stakeholder, lenders might govern the corporates in a significant manner in the Sri Lankan context. ${ }^{1}$ However, no study has examined whether this 'governance executed by lenders' is a key CG mechanism in the Sri Lankan context and its possible effects on the firm financial performance. Therefore, the main objective of this study is 'to examine the effect of Owner-Governance and Lender-Governance mechanisms on Firm Financial Performance of Sri Lankan listed companies'. In this regard, the study defines 'Owner Governance mechanisms (OG)' as the governance practices executed by equity-holders of the firm, primarily the monitoring through

\footnotetext{
${ }^{1}$ The preliminary phase of the current study was based on interviews and questionnaires, in gathering views of the corporate lenders (commercial banks of Sri Lanka), of which the results suggested that lenders play a significant controlling role over their corporate borrowers. This exploratory study further supports the current research problem in the absence of prior literature evidence in the context.
} 
the board of directors and 'Lender Governance mechanisms (LG)' as the monitoring and controlling done by lending banks to the borrowing firm. Use of more precise measurements of both OG and LG mechanisms and also the broader interpretation of Financial Performance will make a significant contribution to the global CG research agenda.

The rest of the paper will proceed as follows: first it reviews the related literature and the respective theoretical stances. Next it describes the methodological approach and the procedure followed by the study. Thereafter, the paper will present the analysis of the related data to address the research question, followed by the concluding remarks.

\section{Literature Review and Hypotheses Development}

\section{Corporate Governance and Firm Financial Performance}

According to the Agency Theory, the separation of ownership and management and self-interest maximising behaviour of both parties results in the conflict of interests, which may not maximise the firm value and the performance (Berle \& Means, 1932; Jensen \& Meckling, 1976; Fama, 1980). In this circumstance, owners in order to secure their interests primarily appoint the board of directors as the monitoring mechanism over the management (Jensen \& Meckling, 1976), which is conventionally considered as corporate governance. Since the board of directors are appointed by owners in order to secure their own interests, the current study defines this as 'owner-based governance mechanisms (OG)'. Many prior research, without defining it as OG, have found that best practices of board of directors increase the firm financial performance and firm value, which in turn increases the interest of owners (Brown \& Caylor, 2006; Balasubramanian et al., 2010; Black et al., 2006; Gompers et al., 2003; Klapper \& Love 2004; Malik \& Makhdoom, 2016; Pillai \& AlMalkawi, 2018).

Apart from the CG executed through the board of directors, there are many more governance mechanisms used by several other stakeholder groups to control and monitor the firm's activities in order to ensure their own expectations. For example, Gillan (2006) provides an extended CG framework that identifies several internal and external governance mechanisms apart from the board of directors. Among these, the governance role of lenders has been identified as a key CG mechanism throughout the recent literature (Tung, 2009; Baird \& Rasmussen, 2006; Nini, Smith, \& Sufi, 2010; Whitehead, 2012 Jandik \& McCumber, 2017; Becher, Griffin, \& Nini, 2018). 


\section{Lenders' Significance in Corporate Governance}

Amongst various stakeholders of a company, the primacy goes to the financiers of its' capital, since they have invested their money in the company and look forward to the outcomes or the benefits (Piot \& Missonier-Piera, 2009; Jiraporn et al., 2013. Accordingly, financiers are stakeholders whose interests are directly affected by the firm's operations Thus, as pointed out by Shleifer and Vishny (1997), CG should fundamentally focus at ensuring the interests of financiers by mitigating agancy costs.

The main financing methods of any corporation are equity and debt, which means the main financiers of corporations are mainly shareholders and lenders. Hence, CG should give preference to satisfy their interests than any other stakeholder. Some companies heavily depend on debt financing and due to that lenders are considered as a vital contributor to the company's capital (Lorca et al., 2011). Under debt financing, private lending is a popular source where banks play a key role as a private lender (Piot \& Missonier-Piera, 2009; Whitehead, 2012; Fields, Fraser, \& Subrahmanyam, 2012). Amongst several types of lenders, banks have become the most significant individual type of lenders around the world, especially in emerging economies where the capital markets for debt are relatively not active (DemirgucKunt \& Levine, 2001; Love, Preve, \& Sarria-Allende, 2007). Private lending has been identified as the most significant source of external financing for public companies where $80 \%$ of public companies maintain private credit agreements (Tung, 2009), where most private lenders are banks (Kahan \& Tuckman 1993; Wilmarth, 2002). Large lenders, such as banks, who provide a significant portion of finance to firms, are also required to be treated in a similar way to major shareholders (Shleifer \& Vishney, 1997). Hence, such corporates should be governed not only for the best interests of shareholders, but also for the betterment of major lenders.

\section{Lender-Monitoring and Firm Financial Performance}

Lender-monitoring is an accepted method to reduce agency costs in general, which means both the agency costs of equity and debt (Florackis, 2008; Jensen \& Meckling, 1976; Smith \& Warner, 1979). As a result of that, ultimately the firm's performance should improve. According to Ang et al. (2000), banks' monitoring over borrowing firms lead those firms to improve their operating efficiency that ultimately result in better financial performance. This means that the spillover effect of lender monitoring efforts tends to give benefits to all stakeholders of the firm, mainly to owners. Smith and Warner (1979) affirm this notion, saying that the optimal set of covenants should balance the conflicts of interest between creditors and shareholders 
in a way that maximises the value of the firm. This indicates that lender governance mechanisms are also to be optimal and it should be beneficial to both the financiers: lenders and owners. Further, it is suggested that lenders' influence on key corporate policy decisions, especially financial and investment policy and management turnover control risks taken by management, may create value enhancement and minimise the potential distress levels of borrower firms (Tung, 2009; Byers et al., 2008).

Debt contracting theory proposes restrictive debt covenants may have both positive and negative effects on firms' operating performance (Smith \& Warner, 1979). Covenants can harm profitability by constraining managers' flexibility to make optimal decisions or undertaking risky projects and investment policies (Jensen \& Meckling, 1976; Chava \& Roberts, 2008). In addition, restrictive loan covenants may also have a positive effect on firm performance by disciplining the manager and reducing managerial slack (Myers, 1977). These mixed results may also be caused by the other organizational, governance and environmental characteristics as well. For example, according to Spyridopoulos (2016, p. 32), "stricter covenants improve the firm's performance only when large shareholders have no presence on the firm's board, when managers are entrenched, when inside directors dominate the board, or when firms face softer competition in their product market".

Some literature argues that lenders' governance mechanisms including restrictive covenants on major policy decisions of the firm may bring several negative consequences which might exacerbate the conflict of interests between owners and lenders (Day \& Taylor, 1998; Anderson, Mansi, \& Reeb, 2004). Bringing a wider and different perspective on the above notion, Tung (2009) suggests that LenderGovernance rivals that of conventional CG, where directors under the extant CG monitor the managers and the operations on behalf of owners to maximise the owners' interests, whereas lenders' monitoring is in favour of their own benefits. This notion anticipates another conflict of governance controls inside the entity which are having two different orientations.

Having analysed that lenders' own governance mechanisms over a firm may conflict with owners' interests and extant CG, it is apparent that the overall firm performance is unpredictable and are risky in a highly levered situation. Hence, it is of utmost importance to investigate and identify the ultimate impacts of these two governance mechanisms in minimising both the agency costs and maximising the firm value, firm's financial performance and firm's sustainability. 


\section{Related Studies in Sri Lanka}

Research in the area of CG is prevalent in Sri Lankan context given both its practical and theoretical implications for the country. Throughout the literature, several studies have examined 'the impact of CG and related characteristics on firm performance' (Heenetigala, 2011; Guo \& Kumara, 2012; Achchuthan, Rajendran, Sivathaasan, 2013; Manawaduge, 2012; Wellalage \& Locke, 2012; Dharmadasa, Gamage, \& Herath, 2014; Azeez, 2015). However, these studies have not been in a consensus regarding the relation between CG practices and firm financial performance, rather they produce mixed results.

Though the CG is a widespread research topic in the Sri Lankan context, there are no published studies on 'Lender-Governance practices' or 'impact of bank monitoring on firm CG mechanisms and firm performance'. The entire CG research discourse has been focused on owner-based CG mechanisms and largely overlooked the other side of the coin. Thus the local literature on CG is incomplete without addressing this concept of lender governance. However, as the bank debt plays a vital role in the capital structure of Sri Lankan corporates (Colombage, 2005; Pratheepkanth, 2011; Vijayakumaran, 2015; Gamlath, 2019), it is promising to inquire the role of this 'Lender-Governance' in them in the conjuncture of existing CG concept. Accordingly, the current study is investigating 'the effect of both lender and owner-governance on corporate financial performance' on which both theoretical and empirical evidences are lacking in the Sri Lankan context.

\section{Theoretical Grounds}

The research issue of the current study is primarily informed by the Agency Theory. As explained under 'Corporate Governance and Firm Financial Performance', Agency Theory was predominantly known to explain the agency relationship between managers and owners. However, the theory of Agency can not be limited to the above relationship, but it is also applicable to any agency relationship where the principal and agents are involved (Ross, 1973; Mtinick, 1973, 2015). According to Jensen and Meckling (1976), there are two main types of conflicts of interests in a levered firm: between owners and managers and between lenders and owner/ managers. The agency costs arising from these conflicting interests are named respectively as agency cost of equity and agency costs of debt.

While owners use monitoring mechanisms such as through the board of directors to govern the corporation and mitigate agency costs of equity, lenders also use monitoring mechanisms such as debt covenants to govern the firm. Smith and Warner 
(1979) clearly explain the debt-related agency problem and controls taken by lenders against those through different types of debt covenants. There are several theoretical and empirical studies examining the role of debt covenants (i. e., lender-monitoring) in reducing the agency cost of debt (Bhojraj \& Sengupta, 2003; Anderson et al., 2004; Klock, Mansi \& Maxwell, 2005; Fields et al., 2012; Francis, Hasan, Koetter, \& Wu, 2012). Thus, the current study, based on these Agency Theoretical arguments, assumes that the both owners' and lenders' governance mechanisms would reduce agency costs of equity and debt, which will ultimately affect increasing firm financial performance.

\section{Hypotheses}

Based on the above-discussed literature and theoretical stances, the hypotheses of the study are developed as below:

\section{Owner Governance and Firm Financial Performances}

$\mathrm{H}_{1 \mathrm{a}}$ : Firm Profitability increases when Level of Owner Governance mechanisms increase

$\mathrm{H}_{1 \mathrm{~b}}$ : Firm Value increases when Level of Owner Governance mechanisms increase

$\mathrm{H}_{1 \mathrm{c}}$ : Probabilty to a firm's distress level (threat to survival) decreases when Level of Owner Governance mechanisms increase

\section{Lender Governance and Firm Financial Performances}

$\mathrm{H}_{2 \mathrm{a}}$ : Firm Profitability increases when Level of Lender Governance mechanisms increase

$\mathrm{H}_{2 \mathrm{~b}}$ : Firm Value increases when Level of Lender Governance mechanisms increase

$\mathrm{H}_{2 \mathrm{c}}$ : Probabilty to a firm's distress level (threat to survival) decreases when Level of Lender Governance mechanisms increase

\section{Research Methods and Data}

\section{Research Approach}

As per the nature of the research issue, this study follows a positivist paradigm. This holds objective ontology since researchers view the research problem as an objective reality and also are independent of observations and interpretations (Firestone, 1987). Associated with this objective view point, the current study follows scientific methods of obtaining knowledge (epistemological stand) where testing hypotheses and arriving at the objective conclusions. Accordingly, this study employs a quantitative methodology that uses research models with dependent and 
independent variables to test the predicted association where all data and analyses are also quantitative.

\section{Conceptual Framework}

Based on the literature survey, it was hypothesised the possible effects of both Owner-Governance and Lender-Governance mechanisms on Firm Financial Performance, in-terms of three main perspectives of firm profitability, firm value and firm survival. In order to address this issue, a conceptual framework was developed which proposes several relationships between the variables as depicted in Figure 1.

Figure 1: Conceptual Framework of the Study

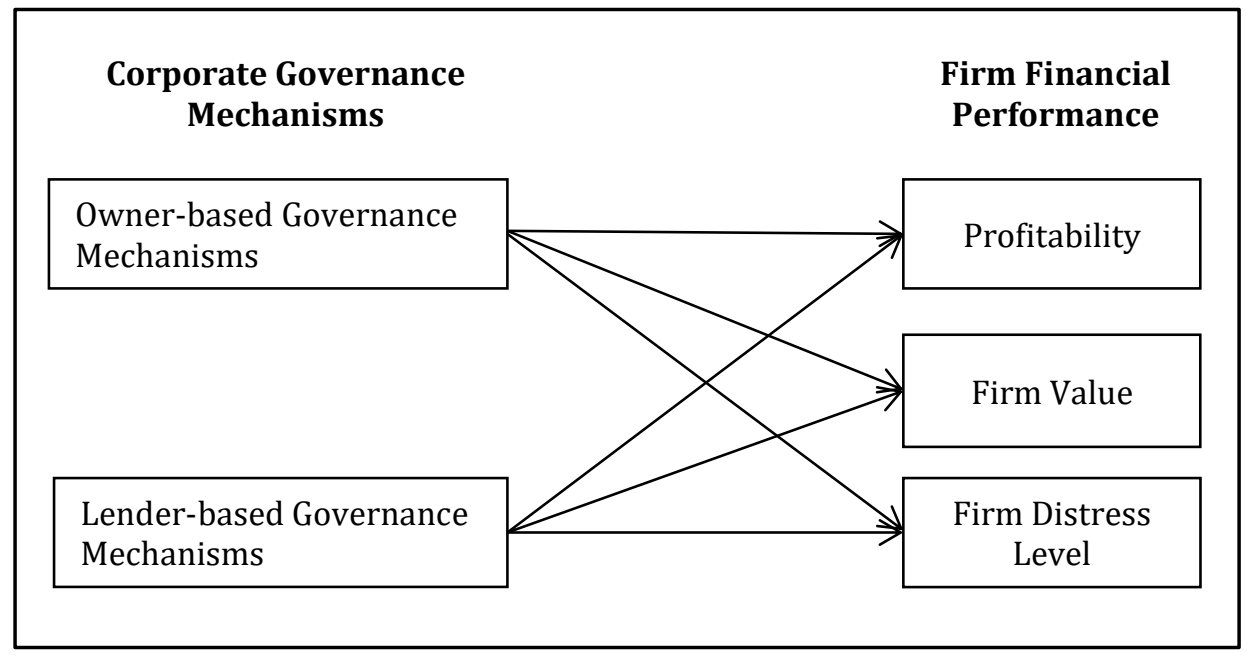

This framework is predominantly developed based on the Agency Theory which is conventionally and frequently used in CG researches. The existing CG models primarily take the owner-oriented CG mechanisms as the independent variable and see its impact on the corporate financial performance. The above conceptual model developed for the current study is going beyond that existing conventional CG model by incorporating few novel concepts as explained earlier. Complying with the Agency Theory, this model hypothesises that broader CG mechanisms will mitigate agency costs and increase the firm financial performance. This model will provide a room to analyse what kinds of different effects would the two types of CG mechanisms have on three mentioned aspects of the firm financial performance. Thus, this conceptualisation allows to identify whether there are any differences between the outcomes of two CG mechanisms which are lead by two main financiars. 


\section{Operationalization of Variables}

The study employs three main sets of variables namely; independent, dependent and controlling. The independent variables represent the two types of CG mechanisms (LG and OG). The dependent variable is measured in terms of three main aspects (Firm profitability, value, and distress level). In order to maintain the accuracy, the predicted relationships are controlled by using two main firm characteristics namely, Firm age and the Firm size. Operationalization of the variables is presented in Table 1 .

Table 1: Operationalization of Variables

\begin{tabular}{|c|c|c|c|}
\hline Concept & Variable & Indicator & Measure \\
\hline Independent & $\begin{array}{l}\text { 1. Owner } \\
\text { Governance }\end{array}$ & $\begin{array}{l}\text { OG Index } \\
\text { (OGI) }\end{array}$ & $\begin{array}{l}\text { Score (Explained under Owner-Governance } \\
\text { Index) }\end{array}$ \\
\hline $\begin{array}{l}\text { Variables: } \\
\text { CG } \\
\text { Mechanisms }\end{array}$ & $\begin{array}{l}\text { 2. Lender } \\
\text { Governance }\end{array}$ & $\begin{array}{l}\text { LG Index } \\
\text { (LGI) }\end{array}$ & $\begin{array}{l}\text { Score (Explained under Lender-Governance } \\
\text { Index) }\end{array}$ \\
\hline \multirow{6}{*}{$\begin{array}{l}\text { Dependent } \\
\text { Variables: } \\
\text { Firm } \\
\text { Performance }\end{array}$} & \multirow[t]{3}{*}{ 1. Profitability } & ROA & $\begin{array}{l}\text { Ratio of } \mathrm{ROA}= \\
\frac{\text { Net income available for common shareholders }}{\text { Average total common equity }} \times 100\end{array}$ \\
\hline & & ROE & $\begin{array}{l}\text { Ratio of ROE }= \\
\underline{\text { Net income available for common shareholders }} \times 100\end{array}$ \\
\hline & & ROI & $\begin{array}{l}\quad \text { Average total common equity } \\
\text { Ratio of ROE }= \\
\frac{\text { Net operating profit after tax }}{\text { Average invested capital }} \times 100\end{array}$ \\
\hline & \multirow[t]{2}{*}{ 2. Firm Value } & \multirow[t]{2}{*}{ Tobin's Q } & $\begin{array}{l}\text { Ratio of Tobin's } Q= \\
\text { Total market value of the firm }\end{array}$ \\
\hline & & & Total assets value \\
\hline & $\begin{array}{l}\text { 3. Distress } \\
\text { Level }\end{array}$ & $\begin{array}{l}\text { Altman's } \\
\text { Z-Score }\end{array}$ & $\begin{array}{l}\text { Score }=1.2 \times(\text { Working Capital } / \\
\text { Tangible Assets) }+1.4 \times \\
(\text { Retained Earnings } / \text { Tangible Assets })+ \\
3.3 \times \text { (EBIT / Tangible Assets })+0.6 \times \\
\text { (Market Value of Equity / } \\
\text { Total Liabilities) }+ \text { (Sales / } \\
\text { Tangible Assets) }\end{array}$ \\
\hline $\begin{array}{l}\text { Control } \\
\text { Variables: }\end{array}$ & 1. Firm Age & $\begin{array}{l}\text { Age in } \\
\text { CSE }\end{array}$ & Natural Log \\
\hline $\begin{array}{l}\text { Other Firm } \\
\text { Characteristics }\end{array}$ & 2. Firm Size & $\begin{array}{l}\text { Total } \\
\text { Assets }\end{array}$ & Natural Log \\
\hline
\end{tabular}




\section{Corporate Governance Mechanisms}

'CG mechanisms', which is the independent variable of the study is twofold; Owner-based CG and Lender-based CG. As the literature suggests, the role of lenders' monitoring mechanisms is to play a vital role in the corporate governance of a firm (Baird \& Rasmussen, 2006; Tung, 2009). Thus, in order to give a complete picture of the concept of CG, this study introduced 'Lender Governance mechanisms' also as one of the key aspects of CG.

Owner-governance index (OGI). The study constructed a CG Index based on the Sri Lankan Code of Best Practices (2013). Many former researchers (Gomper et al., 2003; Brown \& Caylor, 2004; Bebchuk, Cohen, \& Ferrell, 2009; Kowalewski, 2012) have used CG Indices, which are constructed by including the CG principles in measuring or quantifying the $\mathrm{CG}$ practice levels of different firms. The current index primarily covers the owners' governance mechanisms, thus is named as the 'Owner Governance Index' (OGI). This was developed based on the Code of Best Practices and further screened through experts' opinions, where experts represent three main related bodies; namely, the academia, the industry and the professional formulation body of the Code. Based on their average opinion, the original index was filtered and simplified up to a manageable level. In this process, some of the main principles and sub-principles were removed based on the lack of importance in ensuring the owners' interests. Accordingly, the initial number of 78 principles under seven sections was decreased up to 45 principles coming under four sections of 'Directors', 'Directors' Remuneration', 'Relations with shareholders' and 'Audit and Accountability'. The OGI was completed with the data gathered through Annual Reports of the sample companies. Principles listed in the index were cross- checked with the CG practices of the firms and gave 'one' mark if each principle is complied with, otherwise 'zero' marks. Accordingly, the final score of the index for each company is the summation of these individual marks given for each sub-principle. Different companies got different scores out of the total score of 45 (the total number of sub-principles in the index). See Appendix 1 for the principles used in OG Index.

Lender-governance index (LGI). The measurement of Lender-governance mechanisms is not straight-forward in Sri Lanka due to the unavailability of published databases regarding corporate loan contracts. As the literature also lacks a specific measurement technique of this, we developed a comprehensive index to measure the company-specific lender governance mechanisms. The development of this "LenderGovernance Index" (LGI) started with a series of interviews with chief risk officers and other senior officers in Sri Lankan commercial banks which was followed by a 
questionnaire survey among the credit officers of the banks. As the lender governance mechanisms are directly unobserved in the context, the researchers used some proxies (such as loan amount, loan term, the relationship the bank has with the borrowing firm, number of banking relationships of the firm, covenants strictness, lender's quality, debt/assets ratio of the firm, etc.) to reflect the level of bank monitoring exist over the companies. Selection of said proxies was done mainly grounded on three bases, the literature, interviews with top bank officers and the questionnaire survey conducted through all the leading banks in Sri Lanka. The developed LGI was then filled with the data gathered through Annual Reports of the sample companies. A scoring method was used in filling the index and finally a total score reflected the level of lender governance over a company. See Appendix 2 for a sample LG Index.

\section{Firm Financial Performance}

This is the broader dependent variable in the study since it aims to investigate the effects of owner-based and lender-based governance mechanisms on it. Most of the CG studies have used Return on Assets (ROA) and Return on Equity (ROE) to reflect the firm profitability (Klapper \& Love, 2004; Judge, Naoumova, \& Koutzevol, 2003; Brown \& Caylor, 2004; Bhagat \& Bolton, 2008; Haniffa \& Hudaib, 2006). The current study also uses Return on Investment (ROI) to reflect the 'firm's returns on total investment, including both equity and debt' which is also been regularly used by CG researchers (Brown \& Caylor, 2004; Erhardt, Werbel, \& Shrader, 2003; Gani \& Jermias, 2006). This is a better indicator for investors, including both equity and debt holders to evaluate how profitable being the firm for their investments. Next, to reflect the firm value based on firm market performance, the study employs Tobin's Q. This is usually used by the scholars as an alternative firm financial performance measure (Bhagat \& Bolton, 2008; Haniffa \& Hudaib, 2006; Black, Carvalho, \& Gorga, 2009; Hassan \& Halbouni, 2013; Aldehayyat, Alsoboa, \& Al-Kilani, 2016). Further, this study uses Altman's Z-score (Altman, 1968) to reflect the probability of a distress level of a firm which also has been used by other $\mathrm{CG}$ researchers such as Byrd and Mizruchi (2005).

\section{Other Firm Characteristics}

To control the firm characteristics' effect on the proposed relationships, the study has selected two controlling variables which are commonly used in literature, namely, Firm size and Firm age. These are the common and major factors which can affect the firm financial performance. A number of studies (e.g., Mashayekhi \& Bazaz, 2008; Azeez, 2015) have suggested that firm size and age might influence firm performance. Further, Fama and French (1995) suggest that smaller firms 
comparatively have lower ROE than larger firms. Accordingly, firm size has been widely used as a control variable in the empirical analysis of financial performance. Hence, the effects of these variables are controlled in order to filter the impacts of proposed independent variables on firm financial performance.

\section{Population and Sample Selection}

The total population of the study was 288 companies which have been listed in CSE as on $1^{\text {st }}$ October 2016. Out of this entire population, the eligible population was decided by eliminating certain companies as explained below. First, three business sectors were removed namely; Bank, Finance and Insurance sector, Investment trusts and Diversified Holdings. The first two sectors were excluded because of the existence of different and unique CG frameworks for those. Diversified holdings were excluded because of two reasons; firstly to avoid the duplication of the same firm as an individually listed firm and again under the holding company and secondly because the diversified holding firms are just the head offices where business operations are not existing. Then the firms which were listed at the end of 2011 were eliminated since the annual reports and the financials are not published in such a situation. Finally, the firms that moved to the default board for two or more consecutive years were excluded again due to unavailability of annual reports. At the end of this screening process, 172 listed entities were remaining as the eligible population, out of which the highly levered 100 companies (based on the average debt to assets ratio over the five years) were selected as the sample. Leverage of the firms was a significant factor in deciding the sample as the current study focuses on lenderbased governance and to observe that, it is mandatory to have a considerable amount of debt in the entities.

\section{Data Analysis Strategies}

The data of the study were analysed through quantitative techniques namely, descriptive statistics, correlation analyses and multiple panel regression using the Ordinary Least Square method. Descriptive statistics are used primarily to identify the OG and LG practice levels existing in the sample companies. The study makes use of correlation coefficients to find the association between the two main independent variables: OGI and LGI. Two sets of Multiple Panel Regression Models were developed to measure the association between two types of governance mechanisms and three aspects of firm financial performance. Unit root tests, Autocorrelation test, Multicollinearity test and Heteroskedastiticity test are performed for each of the above models. After adjusting for any issues in the model, the regressions are run in two main estimation models, namely, Fixed Effect Model 
and Random Effect Model. The most appropriate model out of these two was selected based on the result of Hausman's Test.

\section{Research Models}

The study uses two main sets of models where the first set is developed to examine the effect of OG level on firm financial performance, and the next set of the models will test the relationship between LG level and firm financial performance.

Set I: $O G$ and Firm Financial Performance

$$
\begin{aligned}
& R O A_{i t}=\beta_{0}+\beta_{1} O G I_{i t}+\beta_{2} A G E_{i t}+\beta_{3} S I Z E_{i t}+\varepsilon_{i t} \\
& R O E_{i t}=\beta_{0}+\beta_{1} O G I_{i t}+\beta_{2} A G E_{i t}+\beta_{3} S I Z E_{i t}+\varepsilon_{i t} \\
& R O I_{i t}=\beta_{0}+\beta_{1} O G I_{i t}+\beta_{2} A G E_{i t}+\beta_{3} S I Z E_{i t}+\varepsilon_{i t} \\
& \text { TOBINQ } Q_{i t}=\beta_{0}+\beta_{1} O G I_{i t}+\beta_{2} A G E_{i t}+\beta_{3} S I Z E_{i t}+\varepsilon_{i t} \\
& \text { ALTMANZ }{ }_{i t}=\beta_{0}+\beta_{1} O G I_{i t}+\beta_{2} A G E_{i t}+\beta_{3} S I Z E_{i t}+\varepsilon_{i t}
\end{aligned}
$$

Set II: LG and Firm Financial Performance

$$
\begin{aligned}
& R O A_{i t}=\beta_{0}+\beta_{1} L G I_{i t}+\beta_{2} A G E_{i t}+\beta_{3} S I Z E_{i t}+\varepsilon_{i t} \\
& R O E_{i t}=\beta_{0}+\beta_{1} L G I_{i t}+\beta_{2} A G E_{i t}+\beta_{3} S I Z E_{i t}+\varepsilon_{i t} \\
& R O I_{i t}=\beta_{0}+\beta_{1} L G I_{i t}+\beta_{2} A G E_{i t}+\beta_{3} S I Z E_{i t}+\varepsilon_{i t} \\
& \text { TOBINQ } Q_{i t}=\beta_{0}+\beta_{1} L G I_{i t}+\beta_{2} A G E_{i t}+\beta_{3} S I Z E_{i t}+\varepsilon_{i t} \\
& \text { ALTMANZ } Z_{i t}=\beta_{0}+\beta_{1} L G I_{i t}+\beta_{2} A G E_{i t}+\beta_{3} S I Z E_{i t}+\varepsilon_{i t}
\end{aligned}
$$

ROA, ROE, ROI are proxies used to reflect firm profitability, where Tobin's Q and Altman's Z are proxies employed to measure firm value and the firm distress level respectively. OGI and LGI are the two independent variables which represent two governance mechanisms. Two control variables are also included in the models: AGE, natural logarithm of firm age and size, natural logarithm of assets. $\beta_{0}$ and $\varepsilon$ indicate the intercept and the error term of the regression respectively.

\section{Results and Discussion}

This section discusses the results of the study in detail along with the respective statistics. Descriptive statistics and the results of correlation analysis are reported in Appendices 3 and 4 respectively. Next, the two sets of proposed models were analysed separately. The specification tests met the assumptions required to run Panel regression. It was confirmed that the data are random based on unit root tests; no auto- 
correlation among the variables based on Durbin Watson Statistic; no heteroskedasticity problem based on Breusch Pagan Godfrey Heteroskedasticity test (BPGH test); no multicollinearity issues according to the Covariance Matrix and the Variance Inflation Factor (VIF). Based on the Hausman's Specification test results it was chosen whteher to run panel regression models with Fixed Effect (FE) or Random Effect (RE).

\section{$O G$ and Firm Financial Performance}

Table 2 presents summary results for the Panel OLS regressions of Set I which were designed to measure the impact of $\mathrm{OG}$ mechanisms on firm financial performance. According to that, the main finding is that OG level affects ROA, ROE and ROI significantly positively, where Tobin's Q and Altman's Z score are not significantly affected. Further, OG have positive impacts on ROA and ROE, which are significant at $5 \%$ level and a positive impact on ROI which is significant at $10 \%$ level. This result indicates that $\mathrm{OG}$ mechanisms influence firm profitability in a significantly positive way. Thus, if the OG level increases in a company, the profitability will be increased significantly.

Table 2: Panel Data OLS Regression Results for OG and Firm Financial Performances

\begin{tabular}{|c|c|c|c|c|c|}
\hline Variable & ROA & ROE & ROI & Tobin's Q & Altman's Z \\
\hline Constant & $\begin{array}{r}13.316^{* *} \\
(0.014)\end{array}$ & $\begin{array}{r}26.281 * * \\
(0.028)\end{array}$ & $\begin{array}{r}22.882 * * * \\
(0.000)\end{array}$ & $\begin{array}{r}6.759 * * * \\
(0.000)\end{array}$ & $\begin{array}{r}15.093 * * * \\
(0.000)\end{array}$ \\
\hline OGI & $\begin{array}{r}0.085^{* *} \\
(0.050)\end{array}$ & $\begin{array}{r}0.215^{* *} \\
(0.030)\end{array}$ & $\begin{array}{l}0.085^{*} \\
(0.093)\end{array}$ & $\begin{array}{r}-0.001 \\
(0.660)\end{array}$ & $\begin{array}{r}0.003 \\
(0.789)\end{array}$ \\
\hline LnAGE & $\begin{array}{r}-0.599 * * * \\
(0.003)\end{array}$ & $\begin{array}{r}-2.053^{* * * *} \\
(0.000)\end{array}$ & $\begin{array}{r}-1.113^{* * * *} \\
(0.000)\end{array}$ & $\begin{array}{r}-0.048 * * * \\
(0.000)\end{array}$ & $\begin{array}{r}-0.054 \\
(0.201)\end{array}$ \\
\hline LnASSETS & $\begin{array}{r}0.221 \\
(0.901)\end{array}$ & $\begin{array}{r}5.545 \\
(0.158)\end{array}$ & $\begin{array}{r}1.502 \\
(0.452)\end{array}$ & $\begin{array}{r}-1.334 * * * \\
(0.000)\end{array}$ & $\begin{array}{r}-3.159 * * * \\
(0.000)\end{array}$ \\
\hline Adjusted $\mathrm{R}^{2}$ & 0.252 & 0.261 & 0.380 & 0.441 & 0.248 \\
\hline F Stat & $4.00 * * *$ & $7.87 * * *$ & $10.42 * * *$ & $94.97 * * *$ & $39.64 * * *$ \\
\hline $\begin{array}{l}\text { Hausman's } \\
\text { test Value }\end{array}$ & 0.013 & 0.000 & 0.000 & 0.000 & 0.000 \\
\hline $\begin{array}{l}\text { No. of } \\
\text { Observations }\end{array}$ & 455 & 455 & 455 & 455 & 455 \\
\hline
\end{tabular}


These results support the Hypothesis 1a which is, Firm profitability increases when OG level increases. This result is consistent with the prior studies (Klapper \& Love, 2004; Judge et al., 2003; Brown \& Caylor, 2004; Bhagat \& Bolton, 2008; Haniffa \& Hudaib, 2006). Klapper and Love (2004) by studying 495 companies in 25 emerging economies found that CG level is positively related to the operating profits measured by ROA. Similarly, Bhagat and Bolton (2008) strongly claim that the CG quality which is measured by two well recognised CG indices (Gompers et al., 2003 and Bebchuk et.al, 2004) is highly positively correlated with operating performance (measured by ROA) of the companies. Brown and Caylor (2004) by measuring the CG level with another comprehensive CG index called Gov-score found that CG Level is significantly positively related to the profitability of a firm. They used ROE, Net profit margin and sales growth as the profitability indicators. In comparison with prior Sri Lankan studies, Manawaduge (2012) has used a similar CG index and found that it is positively related with firm financial performance measured through ROA and ROE. Other Sri Lankan studies that used separate CG aspects such as board size, independence, CEO duality and board committees have found mixed results (Heenetigala \& Armstrong, 2011; Dharmadasa et al., 2014; Azeez, 2015) for each aspect.

Tobin's Q and Altman's Z score are not significantly affected by OG level as per the results of the above analyses. This shows that the Firm value measured by Tobin's $\mathrm{Q}$ and the firm distress level measured by Altman's Z score are not influenced by the changes in the OG level. Accordingly, Hypotheses $1 \mathrm{~b}$ and $1 \mathrm{c}$ are not supported by the results. The results of Hassan and Halbouni (2013) are consistent with the result of this study. They investigated similar relationships in United Arab Emirates' listed firms and did not find any relationship between CG and Tobin's Q. They argued that measures based on market performance are neutral given the economic conditions are ordinary. It should be noted that the current study also was conducted under a normal economic circumstance, which supports the argument made by Hassan and Halbouni (2013). Another recent study on Jordanian firms by Aldehayyat et al. (2016) admitted these findings by ending up with no significant relationship between CG and market performance measured by Tobin's Q. Black et al. (2009) provides a sound justification for these insignificant results on Tobin's Q. They concluded that this relationship between CG and firm value will thoroughly depend on several factors such as the industry of the firm, size of the firm, growth level of the firm and also the country-specific characteristics. Bhattacharya and Daouk (2002) provide another logical ground for this insignificant result, claiming if the CG requirements are not enforceable with the local law, then there is a high probability of resulting significant effect on the market value of a firm by the CG compliance level. Even though, there 
are many past studies which are contrary to present results (Klapper \& Love, 2004; Bhagat \& Bolton, 2008; Balasubramanian et al., 2010; Brown \& Caylor, 2004). However, in comparing results with different countries and different models, the above discussed contextual differences need to be accounted for.

\section{LG and Firm Financial Performance}

Table 3 presents the results on the relationship between LG levels and the firm financial performance of the sample companies. It is found that the LG level has a significantly negative impact on both ROA and Altman's Z score, where the effects on ROE, ROI and Tobin's $Q$ are statistically insignificant. The impact of LGI on ROA is significant at 5\% level where the impact on Altman's Z score is more significant at $1 \%$ level. These results fail to support Hypotheses $2 \mathrm{a}$ and $2 \mathrm{~b}$, but do support the Hypothesis 2c. The two control variables are firm age and size. Age has a significant negative impact on all the firm performance measures except Altman's Z score. Size has a significant positive impact on ROA and a significant negative impact on Tobin's Q and Altman's Z score. Highly significant F statistic values for all the models indicate that the variations in independent and control variables jointly explain the variation of the dependent variable, which suggests the appropriateness of proposed models.

Further discussing results presented in Table 3, it can be claimed that the LG level of a firm significantly decreases the firm operating profitability which is measured by ROA in the study. There are competing arguments in the literature inrelation to the association between lender governance and firm financial performance. Some scholars argue that the LG mechanisms would decrease the agency costs, thus will increase the firm profitability. For example, Ang et al. (2000) claim that the spillover effects of bank monitoring in assuring their interests in a firm will increase the operating efficiency which will lead to increased operating profits. Smith and Warner (1979) also agree with this notion, but they further emphasise that in order to see these positive effects on profits of a firm, the bank monitoring should be at optimal level. They report that there would be some negative outcomes of the debt covenants as well on the firms if those restrict operating and financial flexibility of the firm. This indicates that if the LG is not optimal, there would be negative effects as well for the firm profitability. Adding to this argument on the negative relationship, Chava and Roberts (2008) among others, document that lenders' intervention into CG will reduce the firm profitiability. This second argument is also supported by the theoretical explanations on the different payoff structures connected with debt and equity which lead to divergent interests on how each party would prefer the firm to be operated (Jensen \& Meckling, 1976; Dewatripont \& Tirole, 1994). Accordingly, 
owners with the intention of making high returns, usually promote companies to go for risky projects, opposingly lenders want to minimise the risk exposure of the borrower in order to be secured. The finding of the current study as to 'LG decrease the firm profitability' confirms the latter argument.

Table 3: Panel Data OLS Regression Results for LG and Firm Financial Performances

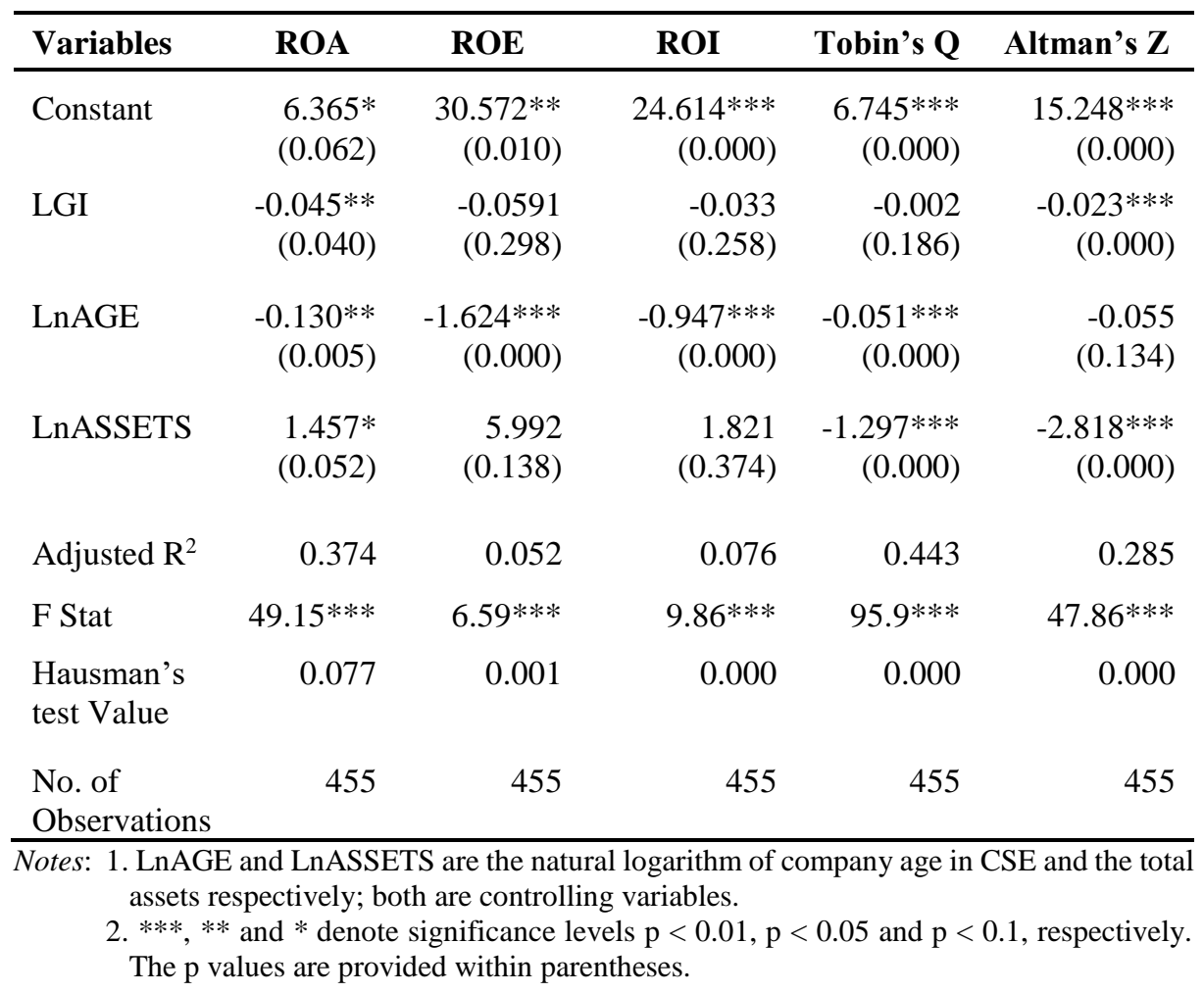

Another significant result of the above set of models is the LG reduces the probability of a firm distress occurring. Significant 'negative' results for the Altman's Z score indicate that the LG leads to a reduction in the probability of a firm distress occurring in the near future, ensuring the firm's endurance. Byrd and Mizruchi (2005) have presented a similar finding that if bankers involved in the governance of a firm, the propensity to distress level is minimised. They also have used Altman's Z score to measure the firm's distress level. Adding to this, Suzuki and Wright (1985) and Hoshi, Kashyap, and Scharfstein, (1990) have found that bank monitoring provides effective and efficient means to resolve financial distress levels of borrowing firms. Furthermore, Elston (2004) concluded that if firms are more influenced by banks, more secured is the firm survival. Literature suggests that lenders' influence to avoid unnecessary risk-taking by the management and owners results in avoiding financial distress of the borrowing firm (Tung, 2009; Byers et al., 
2008). Furthermore, the literature provides that lenders' main concern towards a borrowing firm is to ensure firm continuity, which will ensure the recovery of their lent money (Gale \& Hellwig, 1985; Hart \& Moore, 1998). Thus, the finding of the current study that 'LG will significantly decrease the propensity to distress level of borrower's firm' is consistent with the above literature.

\section{Summary and Conclusions}

This study investigates the effect of two types of governance mechanisms, OG and LG, on firm financial performance. Firm financial performance was broadly measured in the study from three aspects: firm profitability, firm value and probability of firm distress level. The empirical evidence of the study suggets that the OG mechanisms assist in increasing firm profitability while not having any significant effect on firm value and the propensity to distress level. These results convey that a high OG compliance level increases the operating efficiency, through which operating performance is improved. Increased returns on equity and investment show that the prime expectation of shareholders, which is to maximise their wealth, has been attained. Thus, it can be concluded that equity financiers have been able to attain their interests in the entity through their governance mechanisms (OG).

Next, by evaluating the impact of LG level on firm financial performance, it was found that higher LG mechanisms will reduce the firm profitability and increase the firm endurance by mitigating the probability to reach a distress level. Amongst the competing arguments regarding LG and firm profitability, the current study relation to Sri Lankan context is accepting the argument suggesting 'LG mechanisms will restrict managerial flexibility in undertaking profitable (risky) projects, thus reducing the firm profitability'. This result also supports the Risk paradox theory. On the other hand, the results suggest that higher LG levels make a positive impact on firm survival, by significantly reducing the probability of firm distress. This result further explains expectations of lenders where they prefer low risky operating, financial and investment policies over high risky policies which will result in lower operating financial performance but sustain long-term firm survival. Furthermore, findings of the study also suggest that lenders play a significant governance role in Sri Lankan listed entities where they could affect policy decisions which would be reflected in the ultimate financial performance of the firms.

The summarized findings of the study indicate that OG will increase the firm profitability, while having no significant impact on avoiding firm distress and opposingly, LG will reduce the firm profitability while increasing the firm survival. 
These findings suggest that the two financiers have got divergent expectations which they have assured through their own governance mechanisms over the entity (investee). Given that the OG and LG mechanisms are driven by divergent interests of two financiers, those have failed to achieve, on their own, an 'optimal firm financial performance' that maximises all three aspects of firm financial performance.

\section{Implications of the Study}

The current study carries theoretical, methodological and empirical contributions to the extant body of knowledge. As for the theoretical framework of CG, this mainly provides a new classification of the concept as OG and LG. Investigating these two aspects of CG in a single study is a significant theoretical contribution of the study. It is primarily rewarding the Agency Theory by discussing both equity and debtrelated agency conflicts. This exercise has also contributed to the methodological knowledge as well by introducing several improvements to variable measures. Primarily, by introducing the 'Lender Governance Index', this study provides an alternative mechanism to approximate the lender governance level of a context where the debt contracting data are not publicly available through databases. Furthermore, this study is broadening the scope of firm financial performance by using three aspects namely firm profitability, firm value and firm survival. Finally, the findings of the study have many empirical implications. Primarily, the finding on LG practices in Sri Lanka is novel empirical evidence, which brings abundant implications to practitioners and policymakers. Both lending and borrowing institutions may have insights out of the findings, where lenders can ascertain how their monitoring and controlling would affect firms' performance and borrowers can understand how lenders' governance would impact their own performance levels. Policymakers in Sri Lanka might get a new perception about the definition of $\mathrm{CG}$ as a combination of $\mathrm{OG}$ and LG, which may allow broadening the related policies, guidelines and regulations.

\section{Limitations and Future Research Avenues}

This study is based on the Sri Lankan context where no databases (such as Thomson-Reuters' LPC DealScan) are available to get debt contract details such as facility size, maturity, security and covenant types. Hence, the study uses reasonable proxies to approximate the lender governance level, which might somewhat vary from the exact level. However, authors develop an index to increase the accuracy of the approximation and to mitigate this unavoidable contextual limitation. Future studies may consider other firm-level (eg: ownership structure, growth level, level of specialization) and debt contract-level (eg: loan syndication) characteristics which may have an effect on examined relationships. The current study examines the effects 
of two types of governance mechanisms on firm financial performance separately, where future studies may extend this and investigate the combined effects. This may assist in clearly detecting possible conflicts of interests between owners and lenders and also determining the optimal levels of each type of governance in achieving optimal firm financial performance.

\section{Declaration of Conflict of Interest}

The authors declared no potential conflict of interest with respect to the research, authorship, and publication of this article.

\section{References}

Achchuthan, S., Rajendran, K., \& Sivathaasan, N. (2013). Corporate governance practices and capital structure: A case in Sri Lanka. International Journal of Business Management, 8(21), 114-131. doi:10.5539/ijbm.v8n21p114

Aldehayyat, J. S., Alsoboa, S. S., \& Al-Kilani, M. H. (2016). Investigating how corporate governance affects performance of firm in small emerging markets: An empirical analysis for Jordanian manufacturing firms. International Business Research, 10(1), 77-95. doi:10.5539/ibr.v10n1p77

Altman, E. I. (1968). Financial ratios, discriminant analysis and the prediction of corporate bankruptcy. The Journal of Finance,23(4), 589-609. 68. doi:10.1111/j.1540-6261.1968.tb00843.x

Anderson, R. C., Mansi, S. A., \& Reeb, D. M. (2004). Board characteristics, accounting report integrity, and the cost of debt. Journal of Accounting and Economics, 37(3), 315-342. doi:10.1016/j.jacceco.2004.01.004

Ang, J. S., Cole, R. A., \& Lin, J. W. (2000). Agency costs and ownership structure. The Journal of Finance, 55(1), 81-106. doi:10.1111/0022-1082.00201

Azeez, A. A. (2015). Corporate governance and firm performance: Evidence from Sri Lanka. The Journal of Finance and Bank Management, 3(1), 180-189. doi:10.15640/jfbm.v3n1a16

Baird, D. G., \& Rasmussen, R. K. (2006). Private debt and the missing lever of corporate governance. University of Pennsylvania Law Review, 154(5), 12091251.

Bakar, I. S. A., Khan, A., Mather, P., \& Tanewski, G. (2018). Corporate boards and performance pricing in private debt contracts. Pacific-Basin Finance Journal, 50, 144-162. doi:10.1016/j.pacfin.2017.02.007

Balasubramanian, N., Black, B. S., \& Khanna, V. (2010). The relation between firmlevel corporate governance and market value: A case study of India. Emerging Markets Review, 11(4), 319-340. doi:10.1016/j.ememar.2010.05.001 
Bebchuk, L., Cohen, A., \& Ferrell, A. (2008). What matters in corporate governance? The Review of Financial Studies,22(2), 783-827. doi:10.1093/rfs/hhn099

Becher, D. A., Griffin, T. P., \& Nini, G. (2017). Congruence in governance: Evidence from creditor monitoring of corporate acquisitions. doi:10.2139/ssrn.3046910

Berle, A. A., \& Means, G. C. (1932). The modern corporation and private property.New York: Macmillan.

Bhattacharya, U., \& Daouk, H. (2002). The world price of insider trading. The Journal of Finance, 57(1), 75-108. doi:10.1111/1540-6261.00416

Bhagat, S., \& Bolton, B. (2008). Corporate governance and firm performance. Journal of Corporate Finance, 14(3), 257-273. doi:10.1016/ j.jcorpfin.2008.03.006

Bhojraj, S., \& Sengupta, P. (2003). Effect of corporate governance on bond ratings and yields: The role of institutional investors and outside directors. The Journal of Business, 76(3), 455-475. doi:10.1086/344114

Black, B. S., De Carvalho, A. G., \& Gorga, E. (2009). The corporate governance of privately controlled Brazilian firms. Retrieved from http://ssrn.com labstract=1003059.

Black, B. S., Jang, H., \& Kim, W. (2006). Does corporate governance predict firms' market values? Evidence from Korea. Journal of Law, Economics, and Organization, 22(2), 366-413.

Bloomberg, L. P. (2016) Debt-to-equity graph of CSE. 12/1/15 to 12/1/16.

Bowman, E. H. (1980). A risk/return paradox for strategic management. Sloan Management Review, 21(3), pp. 17-31.

Brown, L. D., \& Caylor, M. L. (2006). Corporate governance and firm valuation. Journal of Accounting and Public Policy, 25(4), 409-434. doi:10.1016/j.jaccpubpol.2006.05.005

Byers, S. S., Fields, L. P., \& Fraser, D. R. (2008). Are corporate governance and bank monitoring substitutes: Evidence from the perceived value of bank loans. Journal of Corporate Finance, 14(4), 475-483. doi:10.1016/j.jcorpfin.2008.06.002

Byrd, D. T., \& Mizruchi, M. S. (2005). Bankers on the board and the debt ratio of firms. Journal of Corporate Finance, 11(1-2), 129-173. doi:10.1016/j.jcorpfin. 2003.09.002

Chava, S., \& Roberts, M. R. (2008). How does financing impact investment? The role of debt covenants. The Journal of Finance, 63(5), 2085-2121. doi:10.1111/ j.1540-6261.2008.01391.x

Colombage, S. R. N. (2005). Sectoral analysis of corporate capital structure choiceEmerging market evidence from Sri Lanka. Journal of Asia-Pacific Business, 6(3), 5-35. doi:10.1300/J098v06n03 02 
Day, J., Mather, P., \& Taylor, P. (2014). The effects of corporate board characteristics on loan monitoring decisions. Corporate Ownership \& Control, 11(2), 46-59. doi:10.22495/cocv11i2p4

Day, J., \& Taylor, P. (1998). The role of debt contracts in UK corporate governance. Journal of Management and Governance, 2(2), 171-190. doi.org /10.1023/A:1009978301606

Demirguc-Kunt, A., \& Levine, R. (2001). Financial structure and economic growth: Perspectives and lessons. In A. Demirguc-Kunt \& R. Levine (Eds.), Financial structure and economic growth: A cross-country comparison of banks, markets, and development (pp. 3-14). Cambridge, MA: MIT Press

Dewatripont, M., \& Tirole, J. (1994). A theory of debt and equity: Diversity of securities and manager-shareholder congruence. The Quarterly Journal of Economics, 109(4), 1027-1054. doi:10.2307/2118355

Dharmadasa, P., Gamage, P., \& Herath, S. K. (2014). Corporate governance, board characteristics and firm performance: Evidence from Sri Lanka. South Asian Journal of Management, 21(1), 7-31 .

Elston, J. A. (2004). Bank influence, firm performance and survival: Empirical evidence from Germany 1970-1986. Corporate Ownership and Control, 1(2), 65-70. doi:10.22495/cocv1i2p5

Erhardt, N. L., Werbel, J. D., \& Shrader, C. B. (2003). Board of director diversity and firm financial performance. Corporate Governance: An International Review, 11(2), 102-111. doi:10.1111/1467-8683.00011

Fama, E. F. (1980). Agency problems and the theory of the firm.Journal of Political Economy, 88(2), 288-307. doi:10.1086/260866

Fama, E. F., \& French, K. R. (1995). Size and book-to-market factors in earnings and returns. Journal of Finance 50, 131-155. doi:10.1111/j.1540-6261.19 95.tb05169.x

Fields, L. P., Fraser, D. R., \& Subrahmanyam, A. (2012). Board quality and the cost of debt capital: The case of bank loans. Journal of Banking \& Finance, 36(5), 1536-1547. doi:10.1016/j.jbankfin.2011.12.016

Firestone, W. A. (1987). Meaning in method: The rhetoric of quantitative and qualitative research. Educational Researcher, 16(7), 1--21. doi:10.3102/001318 9X016007016

Florackis, C. (2008). Agency costs and corporate governance mechanisms: Evidence for UK firms. International Journal of Managerial Finance, 4(1), 37-59. doi:10.1108/17439130810837375

Francis, B., Hasan, I., Koetter, M., \& Wu, Q. (2012). Corporate boards and bank loan contracting. Journal of Financial Research,35(4), 521-552. 012. doi.org/10.1111/j.1475-6803.2012.01327.x 
Gale, D., \& Hellwig, M. (1985). Incentive-compatible debt contracts: The one-period problem. The Review of Economic Studies, 52(4), 647-663. doi:10.2307/2297737

Gamlath, G. R. M. (2019). Impact of financial leverage on firm growth of Sri Lankan listed companies. Journal of Management and Tourism Research, 64-83.

Gani, L., \& Jermias, J. (2006). Investigating the effect of board independence on performance across different strategies. The International Journal of Accounting, 41(3), 295-314. doi:10.1016/j.intacc.2006.07.009

Gillan, S. L. (2006). Recent developments in corporate governance: An overview. Journal of Corporate Finance 21(3), 381-402. doi:10.1016/j.jcorpfin. $\underline{2005.11 .002}$

Gompers, P., Ishii, J., \& Metrick, A. (2003). Corporate governance and equity prices. The Quarterly Journal of Economics, 118(1), 107-156. doi:10.1162/ $\underline{00335530360535162}$

Guo, Z., \& Kumara, K. G. A. U (2012). Corporate governance and firm performance of listed firms in Sri Lanka. Procedia-Social and Behavioral Sciences, 40, 664667. doi.org/10.1016/j.sbspro.2012.03.246

Haniffa, R., \& Hudaib, M. (2006). Corporate governance structure and performance of Malaysian listed companies. Journal of Business Finance \& Accounting, 33(78), 1034-1062. doi:10.1111/j.1468-5957.2006.00594.x

Hart, O., \& Moore, J. (1998). Default and renegotiation: A dynamic model of debt. The Quarterly Journal of Economics, 113(1), 1-41. doi:10.1162/ $\underline{003355398555496}$

Harvey, C. R., Lins, K. V., \& Roper, A. H. (2004). The effect of capital structure when expected agency costs are extreme. Journal of Financial Economics, 74(1), 3-30. doi:10.1016/j.jfineco.2003.07.003

Hassan, M. K., \& Halbouni, S. S. (2013). Corporate governance, economic turbulence and financial performance of UAE listed firms, Studies in Economics and Finance, 30(2), 118-138. doi:10.1108/10867371311325435

Heenetigala, K. (2011). Corporate governance practices and firm performance of listed companies in Sri Lanka (Unpublished doctoral dissertation). Victoria University, Melbourne.

Heenetigala, K., \& Armstrong, A. F. (2011). The impact of corporate governance on firm performance in an unstable economic and political environment: Evidence from Sri Lanka. Paper presented at 2012 Financial Markets \& Corporate Governance Conference.

Hoshi, T., Kashyap, A., \& Scharfstein, D. (1990). Bank monitoring and investment: Evidence from the changing structure of Japanese corporate banking relationships. In R. G. Hubbard (Ed.) Asymmetric information, corporate finance, and investment (pp. 105-126). Chicago IL: University of Chicago Press. 
Jandik, T., \& McCumber, W. R., (2017). Creditor covernance. doi: $10.2139 / \mathrm{ssrn} .3209460$

Jensen, M. C., \& Meckling, W. H. (1976). Theory of the firm: Managerial behavior, agency costs and ownership structure. Journal of Financial Economics, 3(4), 305-360. doi:10.1016/0304-405X(76)90026-X

Jiraporn, P., Chintrakarn, P., Kim, J. C., \& Liu, Y., (2013). Exploring the agency cost of debt: Evidence from the ISS governance standards. Journal of Financial Services Research, 44(2), 205-227. doi:10.1007/s10693-012-0142-2

Judge, W. Q., Naoumova, I., \& Koutzevol, N. (2003). Corporate governance and firm performance in Russia: An empirical study. Journal of World Business, 38(4), 385-396. doi:10.1016/j.jwb.2003.08.023

Kahan, M., \& Tuckman, B. (1993). Private vs. public lending: Evidence from covenants. Retrieved from https://escholarship.org/uc/item/1xw4w7sk

Klapper, L. F., \& Love, I. (2004). Corporate governance, investor protection, and performance in emerging markets. Journal of Corporate Finance, 10(5), 703728. doi:10.1016/S0929-1199(03)00046-4

Klock, M. S., Mansi, S. A., \& Maxwell, W. F. (2005). Does corporate governance matter to bondholders?. Journal of Financial and Quantitative Analysis, 40(4), 693-719. doi.org/10.1017/S0022109000001940

Kowalewski, O. (2012). Does corporate governance determine corporate performance and dividends during financial crisis: Evidence from Poland. Retrieved from https://ssrn.com/abstract $=2146168$

Lorca, C., Sánchez-Ballesta, J. P., \& García-Meca, E. (2011). Board effectiveness and cost of debt. Journal of Business Ethics, 100(4), 613-631. doi:10.1007/s10551-010-0699-3

Love, I., Preve, L. A., \& Sarria-Allende, V. (2007). Trade credit and bank credit: Evidence from recent financial crises. Journal of Financial Economics, 83(2), 453-469. doi:10.1016/j.jfineco.2005.11.002

Mashayekhi, B., \& Bazaz, M. S. (2008). Corporate governance and firm performance in Iran. Journal of Contemporary Accounting \& Economics, 4(2), 156-172. doi:10.1016/S1815-5669(10)70033-3

Malik, M. S., \& Makhdoom, D. D. (2016). Does corporate governance beget firm performance in fortune global 500 companies? Corporate Governance, 16(4), 747-764. doi:10.1108/CG-12-2015-0156

Manawaduge, A. S. (2012). Corporate governance practices and their impacts on corporate performance in an emerging market: The case of Sri Lanka (Unpublished doctoral dissertation). University of Wollongong.

Mitnick, B. M. (1973). Fiduciary rationality and public policy: The theory of agency and some consequences . 1973 Proceedings of the American Political Science 
Association. Annual Meeting of the American Political Science Association, New Orleans, LA. doi:10.2139/ssrn.1020859

Mitnick, B. M. (2015). Agency theory. Wiley Encyclopedia of Management, 2, 1-6. doi:10.1002/9781118785317.weom020097

Myers, S. C. (1977). Determinants of corporate borrowing. Journal of Financial Economics, 5(2), 147-175. doi:10.1016/0304-405X(77)90015-0

Nini, G., Smith, D. C., \& Sufi, A. (2010). Creditor control rights, Corporate Governance, and Firm Value. The Review of Financial Studies, 25(6), 17131761. Retrieved from https://www.jstor.org/stable/41485541

Pillai, R., \& Al-Malkawi, H. A. N. (2018). On the relationship between corporate governance and firm performance: Evidence from GCC countries. Research in International Business and Finance, 44, 394-410. doi:10.1016/j.ribaf. $\underline{2017.07 .110}$

Piot, C., \& Missonier-Piera, F. (2009). Corporate governance reform and the cost of debt financing of listed French companies. doi:10.2139/ssrn.960681

Pratheepkanth, P. (2011). Capital structure and financial performance: Evidence from selected business companies in Colombo stock exchange Sri Lanka. Researchers World, 2(2), 171-183.

Ross, S. A. (1973). The economic theory of agency: The principal's problem. The American Economic Review, 63(2), 134-139. Retrieved from https://www.jstor. org/stable/1817064

Shleifer, A., \& Vishny, R.W. (1997). A survey of corporate governance. The Journal of Finance, 52(2), 737-783. doi:10.1111/j.1540-6261.1997.tb04820.x

Smith, C.W., Jr., \& Warner, J. B., (1979). On financial contracting: An analysis of bond covenants. Journal of Financial Economics, 7(2), 117-161. doi:10.1016/ 0304-405X(79)90011-4

Spyridopoulos, I. (2016). Tough love: The causal effects of debt covenants on firm performance. Retrieved from https://efmaefm.org/0EFMAMEETINGS/ EFMA\%20ANNUAL\%20MEETINGS/2017Athens/papers/EFMA2017 $0008 \mathrm{f}$ ullpaper.pdf

Suzuki, S., \& Wright, R. W. (1985). Financial structure and bankruptcy risk in Japanese companies. Journal of International Business Studies, 16(1), 97-110. doi:10.1057/palgrave.jibs. 8490444

Tung, F., (2009). Leverage in the board room: The unsung influence of private lenders in corporate governance. UCLA Law Review, 57, 115-181.

Vijayakumaran, R. (2015). Capital structure decisions, agency conflicts and corporate performance: Evidence from Sri Lankan listed manufacturing firms. International Journal of Accounting and Business Finance, 1(1), 1-14. Retrieved from http://www.maco.jfn.ac.lk/ijabf/index.php/vol-01-issue-01/ 
Wellalage, N. H., \& Locke, S. (2012). Ownership structure and firm financial performance: Evidence from panel data in Sri Lanka. Journal of Business Systems, Governance \& Ethics, 7(1), 52-65. doi.10.15209/jbsge.v7i1.214

Whitehead, C., (2012. Creditors and debt governance. In C. A. Hill \& B. H. McDonnell (Ed.), Research handbook on the economics of corporate law (pp.7576). Edward Elgar

Wilmarth, A. E., Jr. (2002). The transformation of the US financial services industry, 1975-2000: Competition, consolidation, and increased risks. University of Illinois Law Review, 215-476.

\section{Appendix 1: CG Principles in OG Index}

\begin{tabular}{ll}
\hline Reference & Principle \\
No. to & \\
Code & \\
\hline
\end{tabular}

\section{A. DIRECTORS}

\section{A 1 Board}

A 11 The Board meets regularly (At least once a quarter)

A 15 Bring independent judgement on various business issues and standards of business conduct

A 16 Each director dedicates adequate time and effort for the company

\section{A 2 Chairman and Chief Executive Officer (CEO)}

A 20 Clear division of the two positions CEO and the Chairman

\section{A 4 Financial Acumen}

A 40 Board is sound in financial acumen

\section{A 5 Board Balance}

A 51 Board balance with regard to executive and non-executive directors (Higher of 2 or $1 / 3$ of the directors' should be non-executive directors)

A 52 Board balance in respect of independent directors (Higher of 2 or 1/3 of the non-executive directors should be independent)

A 53 Specify the 'independence' of directors

A 54 Declaration of Independent Directors

A 55 Annually determine the 'independence' of directors

A 57 If CEO and Chair-person are same, a 'Senior Independent Director' is appointed

A 510 Where Directors have concerns about the matters of the Company which cannot be unanimously resolved, they should ensure their concerns are recorded in the Board minutes 


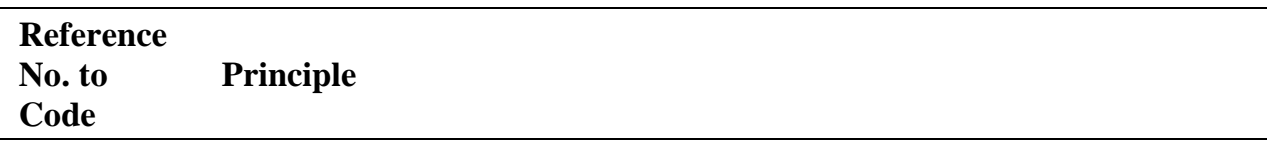

A 6 Supply of Information
A 61 Management's obligation to provide timely information to the board

\section{A 7 Appointments to the Board}

A 71 Nomination committee is established

A 73 Majority or two members whichever higher should be non-executive directors including the chairman

\section{A 8 Re-election}

A 8 Re-election at regular intervals and should be subject to election and reelection by shareholders

\section{A 9 Appraisal of Board Performance}

A 91 Board performance is annually appraised

A 92 Annual self-evaluation

A 93 Disclosed how the evaluations were conducted

\section{A 11 Appraisal of CEO's performance}

A 11 Performance of CEO is annually appraised against the set strategic targets

\section{B. DIRECTOR'S REMUNERATION}

\section{B 1 Remuneration Procedure}

B 11 Remuneration committee is established

B 12 Remuneration committee consists of minimum of two independent nonexecutive directors or exclusively of non-executive directors, a majority is independent whichever is higher

B 13 Chairman is an independent non-executive director

\section{B 2 The level and makeup of remuneration}

B 2 1-4 Performance related elements in pay structure and alignment to industry practices

\section{B 3 Disclosure of Remuneration}

B 31 Remuneration policy and the aggregate remuneration details are properly disclosed

\section{RELATIONS WITH SHAREHOLDERS}

\section{1 Constructive use of AGMs}

C 11 Counting of proxy votes

C 12 Separate resolution to be proposed for each item

C 13 Heads of Board Sub-Committees to be available to answer queries 


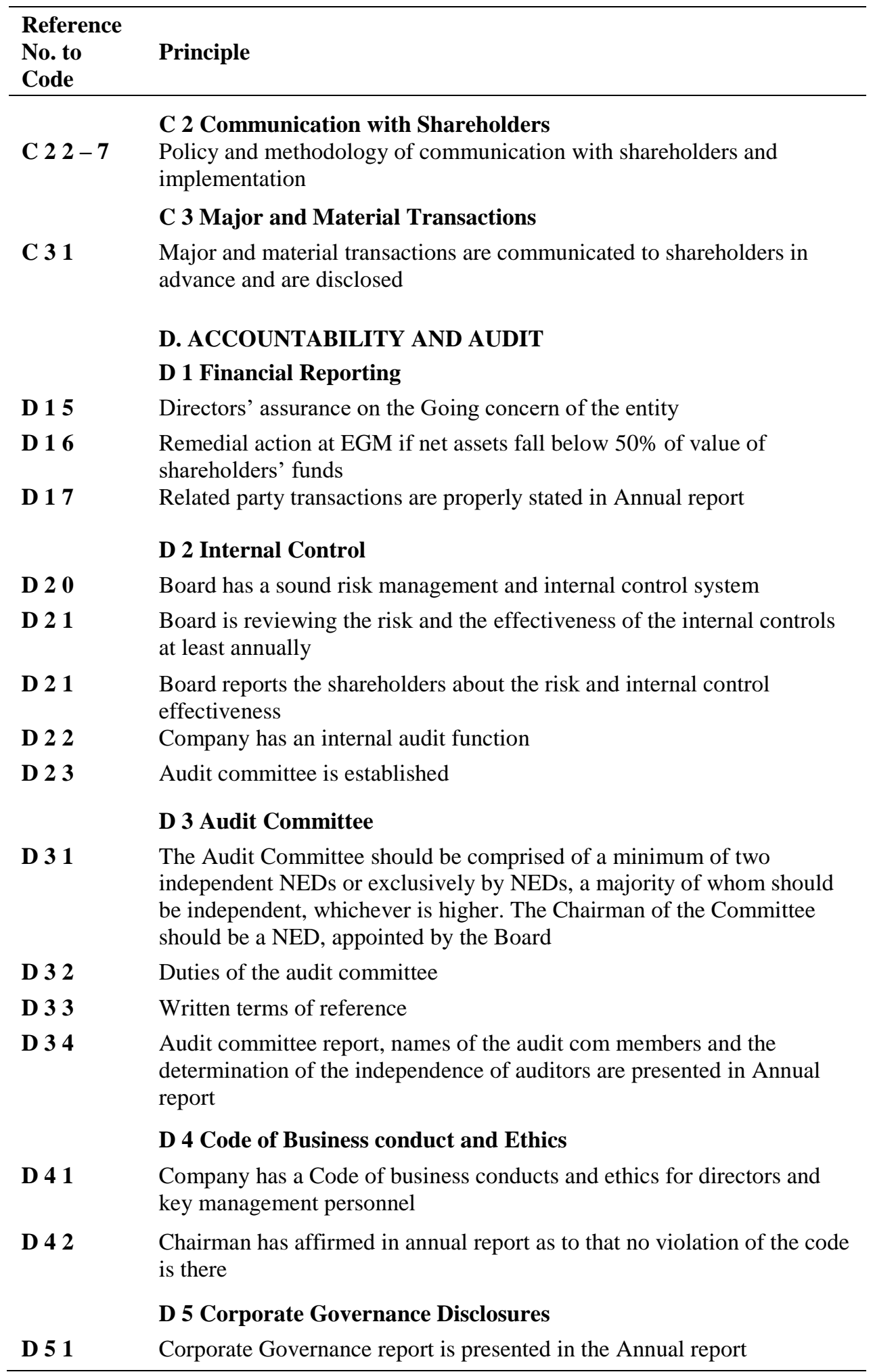


Appendix 2: A Sample LG Index

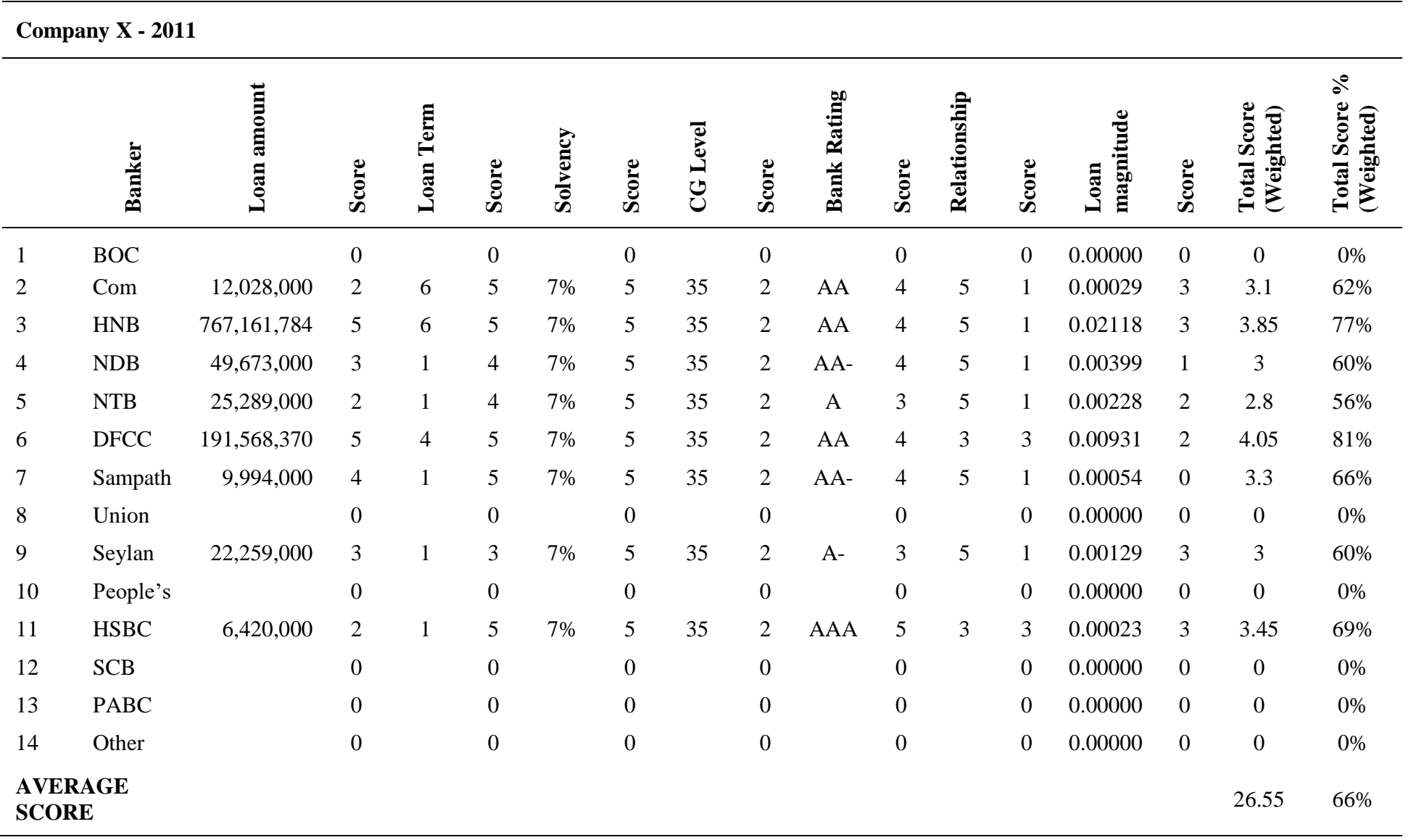


Appendix 3: Descriptive Statistics

\begin{tabular}{lrrrr}
\hline Variable & Mean & Std. Dev. & Min. & Max. \\
\hline OGI & 60.6135 & 18.8598 & 21.4440 & 100 \\
LGI & 53.0571 & 13.5850 & 0 & 81 \\
ROA & 4.9292 & 6.2149 & -6.8535 & 18.6063 \\
ROE & 9.7989 & 13.8213 & -22.8409 & 36.2665 \\
ROI & 6.6789 & 7.4488 & -8.2540 & 21.5759 \\
Tobin's Q & 0.7986 & 0.5962 & 0.1359 & 2.3781 \\
Altman's Z & 2.7597 & 1.6272 & 0.3802 & 6.5579 \\
LnASSETS & 3.5442 & 0.6374 & 1.5570 & 5.0676 \\
LnAGE & 1.2945 & 0.3160 & 0 & 1.8388 \\
AGE & 23.9363 & 12.9609 & 0 & 69 \\
\hline
\end{tabular}

Note: Number of observations $\mathrm{N}=455$

\section{Appendix 4: Correlation Matrix}

\begin{tabular}{|c|c|c|c|c|c|c|c|c|c|}
\hline & ఫ్ర & త్త & 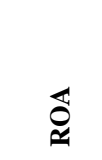 & $\stackrel{5}{0}$ & $\underset{\mathscr{O}}{\approx}$ & $\begin{array}{l}0 \\
\infty \\
\vdots \\
\vdots \\
0\end{array}$ & 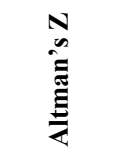 & 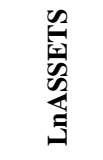 & 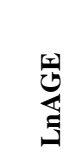 \\
\hline OGI & 1.000 & & & & & & & & \\
\hline LGI & -0.2613 & 1.000 & & & & & & & \\
\hline ROA & 0.1492 & -0.1423 & 1.000 & & & & & & \\
\hline ROE & 0.1508 & -0.0667 & 0.8964 & 1.000 & & & & & \\
\hline ROI & 0.2379 & -0.0706 & 0.8063 & 0.8211 & 1.000 & & & & \\
\hline Tobin's Q & -0.1796 & -0.0466 & 0.2748 & 0.1719 & 0.1471 & 1.000 & & & \\
\hline Altman's Z & -0.0980 & -0.2471 & 0.5234 & 0.3993 & 0.4117 & 0.6533 & 1.000 & & \\
\hline LnASSETS & 0.3813 & -0.0037 & 0.1990 & 0.2439 & 0.3189 & 0.3985 & -0.1887 & 1.000 & \\
\hline LnAGE & 0.0108 & 0.0973 & 0.1564 & 0.1397 & 0.0850 & 0.0977 & -0.0021 & 0.0454 & 1.000 \\
\hline
\end{tabular}

Note: Number of observations $\mathrm{N}=455$ 